\title{
THE PROSPECTS OF ASEAN IN IMPROVING MALAYSIA-INDONESIA RELATIONS: A WAY FORWARD
}

\author{
Ali Jibran \\ Faculty of Politics and IR \\ International Islamic University Islamabad, Pakistan. \\ (ali.jibran33@gmail.com) \\ Doi: https://doi.org/10.22452/ jati.sp2018no1.3
}

\begin{abstract}
Malaysia and Indonesia share many similarities like common religion, history, culture and common ancestry; how ever, despite of this socio-cultural fraternity, the relations between the two countries are replete with discord and friction. The main objective of this study is to find the problematic areas between Malaysia-Indonesia relations and to present ASEAN as a way forward to improve relations between the two countries. The central finding of this study is that is that cooperation level between Malaysia and Indonesia is high in multilateral institutions, however their bilateral relations are alw ays marked with fluctuations. This study selected three key problematic areas in Malaysia-Indonesia relations: conflicting territorial claims, issue related to the Indonesian migrants in Malaysia and cultural conflicts. This study presents ASEAN as a case study and suggests that ASEAN can prove a platform to improve mutual relations between Malaysia and Indonesia because working more closely within the framew ork of ASEAN will cause a spillover effect in socio-political and security related areas between Malaysia and Indonesia. This is an exploratory research and secondary data like the academic research on Malaysia-Indonesia relation has been used in this study to highlight the problems between the two countries and suggest a way forward. This study has used English School of International Relations as theoretical background because the English School suggests that multilateral institutions are pertinent for decreasing the state centric realist apprehensions through creating norms, rules and regulations. This study is divided in three sections: the first section will explain the background of MalaysiaIndonesia tensions, the second section will discuss the English School as theoretical background, and the third section will present ASEAN as a multilateral institution through which the problematic issues between Indonesia and Malaysia can be resolved.
\end{abstract}

Keywords: Malaysia-Indonesia relations, ASEAN, multilateralism, bilateralism 


\section{Introduction}

Malaysia and Indonesia have intertwined histories as historically both the countries were included in ancient empires and kingdoms like Majapahit, Aceh, Srivijaya and Johor-Riau. Kaur (2004) noted that Malaysian-Indonesian interaction has been intense throughout history and common ancestry can be traced between both the countries. The region was a contesting ground among European colonial powers during the colonial era which divided the areas of Malaysia and Indonesia through certain treaties. According to these treaties, Malaya was ruled by the United Kingdom and East Indies were ruled by the Dutch. Malaysia and Indonesia respectively became the successor states of Malaya and Dutch East Indies. Malaya and Dutch East Indies were both dominated by Japan during the World War 2. When the Japanese were vanquished during the World War 2, Indonesia was able to declare its independence in 1945 which culminated in war of independence against the Dutch till 1949.

The British withdrew from Malaya resulting in appearance of three independent states on the map of the world: Malaysia, Brunei and Singapore. The proper diplomatic relations between Malaysia and Indonesia were established in 1957. Malaysia-Indonesia relations exacerbated under Indonesian President Sukarno era. Indonesia vehemently contested the merger of Malaysia with the two former British colonies: Sarawak and Sabah ending in closure of diplomatic relations between the two countries in 1963. After Sukarno, diplomatic relations between Malaysia and Indonesia were restored during the period of Suharto when both the countries manifested willingness in peaceful cooperation with the signing of Bangkok Accord to end rivalry on 1 June 1966 which was followed by Jakarta Accord on 11 August 1966. Till now, the relations between the two countries cannot be regarded as permanently cordial because diplomatic disputes occur one after another which seriously restrict the relations between the two countries (Artifiano, 2009). This study has been divided in three sections.

The first section will mainly deal with the tensions in Malaysia-Indonesia relations. Three key areas have been selected in Malaysia-Indonesia relations in this study: conflicting territorial claims, issue related to Indonesian workers in Malaysia and cultural tensions. It has been argued that the root cause of territorial conflicts between Malaysia and Indonesia is the colonial setting of borders between the two countries as these two countries still struggle to settle their territorial issues. Huge number of the Indonesian workers in Malaysia caused serious tensions in Malaysia as because of porous borders, it is not 
possible to maintain a complete control on the cross border movements. On the other hand, Indonesia claims that Indonesian workers are badly treated in Malaysia and the government of Malaysia provides little help to Indonesian migrants in Malaysia. Furthermore, as culture cannot be successfully divided in the geographic boundaries, certain Malaysian claims and projection of cultural items like dishes and songs, etc., are hotly contested by Indonesia as the government of Indonesia is of the view that most of these cultural items were originated in Indonesia. The Malaysian government suggests that Indonesia manifests unnecessary reaction to these cultural items.

The second part of the study presents theoretical background of the study. This study takes English School of international relations as the theoretical background. Buzan (2004) thinks that the English School suggests that the states develop international society which creates conducive atmosphere for peaceful diplomatic relations among the countries. Multilateral institutions are the key player in this whole episteme of 'international society' because these multilateral institutions limit the freedom of the countries to behave unilaterally and are the main engine to reduce anarchy in global politics.

The third section applies this framework of multilateral institutions on prospects of ASEAN in reducing Malaysia-Indonesia tensions. ASEAN was established in 1967 to provide a platform of cooperation among its member states. ASEAN has proved auspicious in improving Malaysia-Indonesia relations as it has successfully resolved certain standoffs between the two countries. Furthermore, the multilateral platform of ASEAN has potentials to settle Malaysia-Indonesia tensions which are hard to settle through bilateral endeavours by Malaysia and Indonesia.

This research is primarily a qualitative study and the data is gathered through secondary resources. The scholarly articles on Malaysia, Indonesia and ASEAN have been consulted. Especial attention has been paid to the application of the English School theory of international relations at role of ASEAN in improving Malaysia-Indonesia relations. As the English School is very broad, therefore, only those parts of this theory are discussed here that are relevant to institutionalization of mutual interests.

\section{Key Problems in Malaysia-Indonesia Relations}

\section{Territorial Disputes between Malaysia and Indonesia}

Paul Hensel, Heemen Kim and Dale Smith (2008) suggest that the interstate conflicts in post-colonial states are usually the result of establishment of borders by the colonial masters who neglected religious, ethnic and linguistic difference 
which were hotly contested by different ethnic groups. These colonial differences turned in to full blown territorial disputes in post-colonial phase (Hensel, Kim, \& Smith, 2008). Malaysia and Indonesia are also no exception to this as the borders drawn in colonial era have been a constant reason of tension for both the countries. The border problem between both the countries seriously limits the improvement in bilateral relations between Malaysia and Indonesia. Therefore, this study takes the territorial tensions as the most serious problem between the two countries.

Indonesia-Malaysia border entails land border on Borneo Island and maritime boundary on Strait of Malacca in Celebes Sea and South China Sea. The land boundary consists of length of 2,019.5 km separating Indonesian provinces of East Kalimantan, West Kalimantan and North Kalimantan and the Malaysian states of Sarawak and Sabah. Conflicting claims on Malaysia-Indonesia border in the Celebes Sea are main dispute between the countries. Though the dispute was partially settled through the verdict of the International Court of Justice in 2002, but continental shelf between the countries is still bone of contention between the countries. Druce and Baikoeni (2016) suggest that it is noteworthy that Indonesia is an archipelagic state and the United Nations has recognized its status in 1982. According to UN convention, Malaysia is a coastal state. Therefore, Indonesia claims in the light of this UN recognition that it had sovereignty over Ambalat zone. Indonesia demanded water between the outermost reefs and islands and declared all the resources and water under its sovereignty. Four years after this Juanda Declaraation of 1957, Indonesia demanded sovereign rights over the minerals, living and nonliving resources in the region.

Chong Wu Ling and Sivachandralingam Sundara Raja (2018) suggest that Sukarno, the Indonesian president, considered the formation of Malaysia as British policy of neo-colonialism because the British still wanted to control their bases in Singapore and Malaya. Furthermore, Subandrio, the foreign minister of Indonesia, declared in 1963 that Indonesia might opt for policy of conflict with Malaysia. However, Indonesian President Suharto and Malaysian second Prime Minister Tun Abdul Razak Hussein endeavoured sincerely to improve the relation setween the two countries. Special units were established from the both sides to development a framework through which normalization of the relations between the two countries can be materialized (Shafie, 1998).

However, the issue of Ambalat block dispute was caused due to conflicting claims to undecided areas and resources between Malaysia and Indonesia in 1969. This Ambalat issue was discussed in 1969 however no agreement could be reached between the two countries relating to ownership of islands of Ligitan and Sipadan. The indecision about agreed sea border resulted 
in increase in frictions in bilateral relations between Malaysia and Indonesia. However, despite of these territorial disputes the bilateral relations between the two states was peaceful till 2005 when Malaysia's Petronas oil company got exploration concessions. This matter had military repercussions too as navies of both the countries engaged in serious stand-off and aircrafts were used for surveillance. The impact of this territorial struggle was felt on the domestic politics too as the mass media and public opinion in Malaysia as well as Indonesia became highly nationalist and harsh towards the other state. However, in coming years both the states were successful in de-escalation. ASEAN provided them the much needed help to improve their relations through Treaty of Amity and Cooperation and through sending the case of this issue to the ICJ (Druce \& Baikoeni, 2016).

Tangsubkul (1982) opines that Malaysia endorsed the Continental Shelf Act to justify its claim on continental shelf in 1966 in the Celebes Sea and South China Sea. After four years in 1969, Malaysia issued an ordinance in its constitution known as Emergency Ordinance to extend territorial sea for Malaysia (Tangsubkul, 1982, pp. 11-12). The new Malaysian claims of its EEZ were in conflict with Indonesia's claims on Ambalat waters. Indonesia suggested that the ICJ decision was only concerning sovereignty over Ligitan and Sipadan not on the rights to the Amabalat zone. The dispute turned more serious in 2004 and 2005 when Indonesia gave the US Company Unocal permission to explore gas and oil in Ambalat block. On the other hand, Malaysia permitted a Royal Dutch Shell to explore oil that came in direct conflict with Unocal. The bilateral relations between Malaysia and Indonesia reached to lowest ebb as navies of both the countries were seen patrolling posing a major threat of a serious conflict. The issue of territorial claims is still unresolved despite of endeavours of improvement in relations.

\section{Issue Related to Indonesian Migrants Working in Malaysia}

Liow (2013) writes that the huge number of illegal Indonesian labours in Malaysia is considered one of the main reasons behind troubled MalaysiaIndonesia relations. On the other hand, the Indonesian authorities and public criticize the harsh behavior of Malaysian employees with Indonesian workers in formal as well as informal sectors and inaction of the Malaysian government to stop exploitation of the Indonesian labours (Wahyono, 2007). The Indonesian workers are said to be suffering from human trafficking, illegal immigration, crimes and extortion (Liow, 2003). The rapid development and modernization of Malaysia during 1980s and 1990s attracted a lot of Indonesian workers who considered Malaysia as an attractive destination to improve their lots. Liow 
(2013) notes that the movement of workers from Indonesia to Malaysia accelerated in the aftermath of the Asian Financial Crisis in 1997 which shook the economies of East Asia to the core. A lot of the Indonesian workers lost their jobs and huge influx of the Indonesian workers entered in Malaysia culminating in serious social problems in Malaysia. Though illegal labours from Indonesia has been a main source of tension and both the countries have endeavoured numerous times to solve the problem, however, the issue is still unresolved because of diplomatic uncertainty between the two countries. To understand the current Malaysia-Indonesia diplomatic problem pertaining to labour issue, very short overview of Malaysia Indonesia historic communication will be discussed in the preceding paragraphs.

Kaur (2004, p. 6) suggests that Malaysia and Indonesia have many common similarities like Malay ethnicity, religion and language (Bahasa Malaya). These shared characteristics resulted in close economic and cultural relations between the two countries. It was common for the Indonesians to travel to Malaya for goods trade and other economic activities. Because the people of both the countries regarded each other as members of same ethnicity, therefore assimilation was easy. The first major migration occurred from Indonesia to Malaysia towards the start of the $20^{\text {th }}$ century when the British government in Malaysia decided to employ Indonesians for plantations projects in Malaysia. The workers from Indonesia suited the colonials well in Malaysia as the workers from India and China had different language and culture; while the assimilation of the Indonesian workers in Malaysia was easy due to same culture and language (Kaur, 2004). After the independence from colonial powers, territorial dispute occurred between Malaysia and Indonesia over the region of North Borneo. This diplomatic row discouraged the numbers of the Indonesian workers who wanted to come to Malaysia in 1960s. However, 1970s witnessed significant increase in the number of flux of the Indonesian migrants in Malaysia. Kaur (2004, pp. 15-16) highlighted these causes of surge in the number of Indonesian labours in Malaysia: the initiative of the New Economic Policy (NEP), export led industrial development and massive increase in foreign direct investment. On the other hand, the Indonesian government welcomed this situation because the domestic markets in Indonesia were unable to accommodate an army of the unemployed workers (Arifianto, 2009, p. 619).

Wahyono notes that according to the data revealed by the Malaysian Immigration Department in 2005, out of 1581755 foreign workers in Malaysia, 1105083 workers were Indonesia (Wahyono, 2007, p. 28). Transnational migrations of the workers are regarded as a controversial issue disrupting the diplomatic relations among the states. Because of increased interconnectedness, 
labours from the developing countries are forced to look for their livelihood in states other than their birth. The migration of workers from one country to another sometimes complicates the relations between the immigrants and the natives because of a number of problems: economic competition, limited jobs and problems relating to law and order. Such economic and security related issues push the central governments of the destination states to introduce stringent immigration laws (Arifianto, 2009).

Along with legal workers, huge influx of illegal workers entered in Malaysia without legal documentation. On the other hand, the presence of Indonesian workers, especially the illegal workers, was economically lucrative for the Malaysian employees because of opportunities of cheap labour. Due to weak bargaining position of the illegal workers, illegal workers were vulnerable in the face of diverse legal problems related to law and order. Because of failure of Malaysian government to introduce legal framework of managing the recruitment of the Indonesian labours, the number of illegal Indonesian workers in Malaysia increased menacingly. The number of the Indonesian workers was estimated at 100,000 in 1981 and this figure jumped to 1 million in 1987. This number sky rocketed to 1.9 million in 1997 and out of this more than $50 \%$ were illegal migrants (Arifianto, 2009, pp. 619-620). Such a huge flux of the Indonesian workers created alarms in Malaysia as the Malaysian government vowed to regulate and limit the numbers of the Indonesian workers. Since then, the Malaysian government tried to introduce different measures, however all such efforts ended in fiasco.

The Medan Agreement, signed in 1984, was aimed at regulation of Indonesian labours in plantation sector; however, soon this legal framework was expanded to other sectors too. When the Medan Agreement proved futile to stop the flux of the Indonesian illegal workers entering in Malaysia, the Malaysian government decided to legalize the illegal Indonesian labours in Malaysia which did not prove successful too. Another legalizing endeavour aimed at legalizing illegal Indonesian workers employed in plantation met with the same fate in 1989. Towards the early 1990s, the Malaysian government decided to sternly deal with theillegal migrant issue. The Operation Nyah 1 and 2 were launched by the Malaysian police deported 147,000 Indonesian illegal workers and hiring of new workers from Indonesia was discouraged. All such efforts to reduce Indonesian workers were failed because these initiatives were very difficult to be managed strictly for a long time. After this, the Malaysian authorities tried to limit the number of the Indonesian workers off and on, however, the demand of Indonesian workers from the Industrial circles in Malaysia put serious constraints to these efforts. Lumayag and Sail (2014, p. 102) opine that the 
successful diffusion of the Indonesian workers in Malaysia is very difficult because of very problematic environment in which the workers have to work.

The most provocative issue between Malaysia and Indonesia occurred in 2002 when Malaysian government announces "Hire Indonesian Last" policy in reaction to a riot by more than 400 Indonesian workers in a factory in state of Negeri Sembilan clashed with police. Following the riot, the Malaysian government decided to put a temporary ban to discourage the flux of Indonesian workers through unprecedented harsher steps. As a result of diametric change in the policy of Malaysia, almost 400,000 Indonesian workers were forced to leave. Ford (2006) suggests that most of this exodus occurred through the city of Nunukan. The huge flux of the Indonesian workers created humanitarian crisis in which 70 workers lost their lives and hundreds were seriously ill (Ford, 2006, p. 239). This incident is remembered as Nunukan incident in the Indonesian government claimed that the Malaysian government was fully responsible for the tragedy. In the aftermath of row over Indonesian labour issues, the government of Indonesia decided to place a moratorium on Indonesian workers to seek employment in Malaysia (Elias, 2013).

Despite of several initiatives from both the countries, Indonesian labour problem has not been solved yet because it seems that the governments of both the states have very different approaches to solve the problem. When Malaysian government is adamant in reducing significantly the numbers of illegal labours in Malaysia, the Indonesian government wants Malaysia to accommodate majority of Indonesian workers because Indonesia economically is not in a position to settle all the deported illegal Indonesian workers from Malaysia. Dato Seri Haji, the Director of Immigration Department of Malaysia, claimed that up to 6315 Indonesian illegal workers have been detained from January 1 to May 24, 2018. Furthermore, he said that Indonesia has the highest numbers of illegal workers in Malaysia (tempo.co, 2018). On the other hand, the Indonesian Labour Minister Hanif Dhakiri had suggested that Indonesian workers issue in Malaysia had worsened because of strict labour policies of Malaysian government and if Malaysia introduced flexible program with cheap repatriation then many illegal Indonesian workers would join the program (The Sun Daily, 2017).

\section{Cultural Tensions between Malaysia and Indonesia}

The relationship between Malaysia and Indonesia is considered as one of important relations in Southeast Asia because Indonesia is fourth populous country in world and Malaysia is considered as one of the important emerging economies. Peace and stability in Southeast Asia depend to a large extent on the 
relations between the two countries. Malaysia and Indonesia share common religion like similar language and ethnic history. This shared culture and language is beneficial in connecting people. Mhd. Nur $(2018$, p. 64) suggests that the Strait of Malacca in a very unique way connects the Malays living in Indonesia and Malaysia through economic, social and political ways. In fact, the Strait of Malacca connects both the countries in inseparable way which means that the culture of both the coun tries is same. Dollah and Mohamad (2007) are of the view that despite of serious troubles, barter trade between Malaysia and Indonesia has potential to increase the people to people connection especially in areas of Tawau and Nunukan and Tarakan.

For example, Indonesian films and dramas are famous in Malaysia and Malaysian singers and animation industries are very popular in Indonesia. However, despite of this cultural affinity, culture has also become a disruptive force between Malaysia Indonesia relations. In the previous years, the problems like conflicting claims origin of dance, dishes and other similar cultural icons have seriously restricted the relations between the two countries. In the coming paragraphs cultural differences between the two countries will be explained briefly.

Culture cannot be separated from human life and is regarded as one of the most complex factors of social life (Nizar, 2017, pp. 31-32). Culture based discord between Malaysia and Indonesia is a new kind of interstate dispute in developing countries as conflicts prior to this were related to boundary disputes and other similar colonial legacies. The 'Kashmir Issue' is the major bone of contention between India and Pakistan while the differing claims on land of Palestine and Israel has been the main discord between the Arab world and Israel (Nizar, 2017, p. 33). In the $21^{\text {st }}$ century, Malaysian government decided to extend its development approach as it introduced cultural promotion in its development policy. Nizar (2017, p. 31) suggests that Malaysia had ignored culture in its early development approaches. When Malaysia expended its cultural industry through performing festivals, exhibitions and cultural shows; this Malaysian cultural promotion campaign was challenged in Indonesia as Indonesia claimed that most of the cultural icons projected as having Malaysian roots were in fact Indonesian not Malaysian.

Through the use of efficient tourism campaign, Malaysia was successful in featuring some cultural icons as having Malaysian roots: song Rasa Sayang, shadow puppet show, batik and barongan dance. The alleged nomination of Malaysia in UNESCO Representative List of Intangible Cultural Heritage and numerous Indonesian forms having Malaysian basis including wayang, angklung, batik and gamelan has infuriated Indonesia. The Indonesians hotly 
contested these Malaysian claims to these cultural signs, culminating in conflicts of Pendet controversy in 2009. A serious diplomatic row between Malaysia and Indonesia occurred in which a Discovery Channel program titled "Enigmatic Malaysia" projected traditional Indonesian dance (Pendet) having Malaysian roots (Fitzpatrick, 2009). Clark (2013) posits that the Malaysian government posited that the documentary was not produced by the Malaysian government, therefore the allegation of the cultural theft is unjustified. In addition to this, origins of multiple dishes are also disputed between Malaysia and Indonesia. Furthermore, the Indonesian are also of the view that the Malaysian national anthem is a plagiarized from an Indonesian ballad. Such matters have created serious resentment in Indonesia and several massive protests have been witnessed in Indonesia on cultural theft from Malaysia. On the other hand, the Malaysians are worried at increased anti-Malaysian populist stance in Indonesia and are questioning the logic behind such cultural sensitiveness which is very difficult to be differentiated properly and cannot be confined indefinite boundaries (Clark, 2013).

\section{Theoretical Framework: The English School of International Relations}

Realism and liberalism are regarded as the two most important post-World War2 international relations theories. Walt (1998) thinks that Realism takes the international politics as unending struggle among sovereign states which function on incentive of self-in terest, thus conflict are bound to happen in global politics (Walt, 1998, pp. 29-32). In contrast to realism, liberalism suggests that it would be a mistake to consider international politics only as 'war of all against all' as despite of anarchy at international level there are lot of positive things to cherish like the emergence of international organizations which have the capacity to limit the effects of anarchy. As for as English School of International Relations is concerned its view can be regarded in between the extremes of realism and liberalism or 'via media' between realism and liberalism (Buzan, 2014). The central point of the English School is that states have been successful in devising an 'international society' or 'international society' in which the states are not bound to surrender their sovereignty. In such type of international society, there is 'low level of conflict' and 'high level of order' (Linklater, 2005).

The idea of 'international society' emerged in aftermath of various meetings conducted by British Committee, which was formed in late 1950s to evolve a new theory of international politics in England. The concept of 'international society' was historical, sociological, legal and philosophical way of thought; therefore, the English School emerged very different to mechanistic way 
of IR that was predominant in Europe and the US in aftermath of World War 2 (Buzan, 2014). The notable thinkers in the English School are Martin Wight, Hedley Bull, Herbert Butterfield, Adam Watson, Robert Jackson, Tim Dunne, Nicholas Wheeler and Barry Buzan (Wang \& Buzan, 2014). English School emerged as a full-grown 'third debate' in international relations because of the endeavours of these figures. The first debate is considered as the struggle between the realists and the liberal about the nature of international politics; while the behaviorialists and the traditionalists opposed each other in the second debate (Wang \& Buzan, 2014).

The English School suggests that states try to create societies (Karmazin, 2014) like humans who develop societies to live (Wang \& Buzan, 2014). Institutions play central role in the emergence of 'international society' according to understanding of English School because the English School proposes that institutions work as a tool through which international society restricts the freedom of states to pursue their self-centric interests. Barry Buzan is of the view that the English School gives a lot of significance to institutions due to three reasons: at first, institutions are important part of 'international society', secondly, institutions can explain 'order' in international societies, thirdly institutions distinguish English School from other IR theories (Buzan, 2004). The emphasis of the English School on institutions will be applied at ASEAN and it will be discussed in the next section that how ASEAN can prove helpful for improving relations between Malaysia and Indonesia in the selected three problematic areas.

\section{The Prospects of ASEAN in Improving Malaysia-Indonesia Relations}

Long (2014) notes that the world has become globalized and isolation is not the best option in an interconnected world. Globalization can be considered as a phenomenon that encourages integration and interaction between the people and governments through the advancement in communication, transportation through the use of improved technology. To foster interconnectedness among the countries of Southeast Asia, the Association of Southeast Asian Nations (ASEAN) was introduced in 1969. The main objectives of ASEAN were to improve intergovernmental cooperation through facilitating political, economic, security, socio-cultural and educational integration among the countries of the region. Malaysia, Indonesia, Singapore, Philippines and Thailand were the initial members of ASEAN, however its membership has been extended to Cambodia, Brunei, Vietnam, Laos and Myanmar. The primary principles of ASEAN are 
social progress, economic growth and social evolution among the member states (Long, 2014).

Another purpose of establishment of ASEAN was to checkmate the rise of communism in Southeast Asia and the US provided financial and strategic help to the member states of ASEAN. In 1960s, the countries of Southeast Asia alleged that Maoist China was interfering in their domestic issues and was encouraging Maoist revolution in these countries. This raised alarms in the region as well in the US as the American government was of the view that Marxist revolutions in counties of Southeast Asia would prove highly detrimental for the global capitalist economic system, therefore the US was adamant in supporting countries of Southeast Asia against fighting Maoism.

Kim and Selvaraju (2010) suggest that when ASEAN performance had been phenomenal, it faced serious challenges because of state centric realistic concerns of some of member states, especially related to conflicting interests in the South China Sea. Furthermore, to increase efficiency of ASEAN, member states should endeavour to forma community in the region. Yazid (2013, p. 30) is of the view that establishment of ASEAN proved especially auspicious to Malaysia-Indonesia relations as relationship between the two countries prior to ASEAN was colored with discord. Pre ASEAN animosity between the two countries can be attributed to the troubled colonial and post-colonial memories. The Indonesian first President Sukarno (1949-1966) considered Malaysia as a country having no will of its own and promoting interests of previous colonial masters the British. Sukarno's view that the countries which had broken the shackles of colonialism should follow their own independent domestic and foreign policy and should be free from all sort of pressures. Because of such Sukarno's political ideas, Indonesia during 1960s became very close to the USSR and China (Hindley, 1963). However, the radical policy of Indonesia changed after the fall of Sukarno's regime as the new government under Suharto was less favourable to communist countries and movements, therefore working under the auspices of a regional organization were bright which could checkmate communism in Southeast Asia. It is very hard for the countries having conflictual interests to cooperate and come out of security dilemmas; only regional organizations can help the countries to improve their bilateral relations. Therefore formation of ASEAN in 1967 can be considered as the tu rning point in histories of Malaysia and Indonesia (Yazid, 2013).

ASEAN can be regarded as a successful organization as it has avoided interstate conflict and achieved stability and regional peace. ASEAN uses formal methods like diplomacy as well as informal approaches to achieve regional order. The main objective of ASEAN is to manage conflicts through dialogue and 
avoid use of coercion which was reflected in the Bangkok Declaration in 1967, the ASEAN accord and the Treaty of Amity and Cooperation in Southeast Asia (TAC) signed in 1976. It was vowed in the ASEAN Accord that such kind of economic, political, cultural and security environment will be created that would prove conducive for good relations among the countries. ASEAN has been an arrangement which can help states to coexist despite of their religious, political and cultural differences. If interstate conflict occurs, countries have developed a procedure in which restraint can be maintained despite of conflicts (Askandar, Bercowtch, \& Oishi, 2002).

ASEAN's mandate expended from a limited mandate to a broader agenda. ASEAN has successfully reduced security concerns of the states of the region. The growth in membership, especially in 1990s, suggests that the states of the region depend on ASEAN because only ASEAN can prove a platform where diverse problems of the states can be resolved peacefully. 'ASEAN way' is a term that is used for the policy of non-interference adopted to peacefully settle the disputes. Similarly, East Asian Community is another term that is used to explain the desire of the member states of ASEAN to peacefully settle the problems of Southeast Asia. Therefore, it can be suggested that by working closely under the auspices of ASEAN, territorial, migrant and cultural disputes between Malaysia and Indonesia can also be resolved.

According to Druce and Baikoeni (2016), the conflicting claims on the continental shelf situated in the Celebes Sea between Malaysian state of Sabah and Indonesian province of North Kalimantan, known as Ambalat block, is regarded the most controversial issue between Malaysia and Indonesia relations since Konfrontasi came to an end in 1966. Although the Ambalat dispute has not been resolved yet certain conflict minimizing strategies have been adopted to peacefully resolve the issue, which has contributed immensely to "ASEAN Way Management". These efforts have avoided imminent danger of conflicts between the two countries as the bilateral negotiations replaced a naval stand-off. There are reports that Malaysia and Indonesia agreed to jointly explore the economic benefits in Ambalat sea floor. This management endeavours include maintaining a border commission and establish a common understanding that how both the parties should expect to behave. Through these efforts, Malaysia and Indonesia have been successful in transforming incompatibilities in manageable issues.

Therefore, it can be concluded that there is no quick solution to this territorial discord between the two countries, therefore ASEAN should expend its role by including bilateral conflicting parties in its agenda. The framework of ASEAN will provide both the states another alternative to their bilateral channels because it has been seen that bilateral channels between Malaysia and Indonesia 
don't prove productive therefore ASEAN can cover the deficiencies in the bilateral relations between the two countries. Similarly, the tensions related to culture between the two countries can also be dealt under the framework of ASEAN. The regional organizations having multi-county members have the cultural areas which allow the assimilation of multi culture. Thus regional organizations can seriously reduce the cultural conflicts among the countries having troubled relations related to culture. ASEAN also has a specific committee for Culture and Information (ASEAN COCI) established in October 1978 to promote cooperation in fields of information and culture to enhance solidarity and mutual understanding among the ASEAN countries. ASEAN COCI arranges workshops on regular basis to allow and promote cultural diversity in which members of civil society from a diverse background are encouraged to attend these workshops.

In addition to ASEAN COCI, ASEAN Ministers Responsible for Culture and Arts (ARMC) is committed to promote culture to improve overall culture of ASEAN. Furthermore, the ASEAN Strategic Plan for Culture and Arts 2016-2025 aims to assist intercultural dialogue in ASEAN by engaging different stakeholders. These different cultural bodies under the auspices of ASEAN provide golden opportunity to Malaysia and Indonesia to come out of their cultural specificness. These ASEAN frameworks will enable the civil society of both the countries to interact on a regular basis. This interaction can play a vital role in overall improvement of cultural disputes between the two countries as increase in interaction will generate respect for the culture of other states. Moreover, working under the frameworks of ASEAN bodies will produce a common sense of belongingness among the public of member states which can potentially decrease the cultural sensitiveness between Malaysia and Indonesia.

Usually states have the various resources to construct their agenda in nationalist tone but the enlightened civil society in the countries whose governments have the conflictual in terests can enforce their state to change their approaches. Thus public diplomacy can, which is possible only through cultural respect, avert states conflicts. The civil society of Malaysia and Indonesia can play a very important role under the framework of ASEAN in overall improvement of bilateral relations between Malaysia and Indonesia. On the similar lines, migrant issue between Malaysia and Indonesia can also be resolved by working closely within the framework of ASEAN because ASEAN enables the two countries to resolve their differences related to migrant problem. Furthermore, ASEAN can provide the opportunities to both the countries to come together and resolve their differences by assisting and facilitating. The ASEAN Plan of Action in addition to ASEAN Convention against Trafficking in 
Persons, Especially Women and Children (ACTIP) can provide comprehensible plan to the member states to control all sort of human trafficking. If the member states of ASEAN are successful in cooperating closely under the auspices of human trafficking and illegal migration in ASEAN, this can address to the Malaysian grievances of illegal entrance of hundreds of thousands of Indonesian workers in Malaysia and causing serious socio economic problems in Malaysia. On the other hand, this can also provide relief to the Indonesian government as Indonesia constantly claims that the Indonesian workers are target of various kinds of violence because such allegations in future can be legally addressed by ASEAN.

\section{Conclusions}

This study deals with the contemporary problems in Malaysia-Indonesia relations and presents ASEAN as a suitable regional organization that can help Malaysia and Indonesia to improve their bilateral relations. This study discusses three key problematic areas in Malaysia-Indonesia relations: conflicting territorial claims, issue related to the Indonesian migrants in Malaysia and the cultural tensions between the two countries. This research has found out that the regional organization of ASEAN has helped Malaysia and Indonesia to settle their bilateral relations through institutionalization of mutual interests and identities. Through applying the English School Theory of International Relations, this study suggests that if Malaysia and Indonesia work more closely under the auspices of ASEAN, multilateral framework of ASEAN has potential to substantially improve the problematic areas in the bilateral relations between the two countries through harmonizing their interests and reducing their conflicts.

\section{References}

Arifianto, A. R. (2009). The securitization of transnational labor migration: The case of Malaysia and Indonesia. Asian Politics \& Policy, 1(4), 613-630.

Askandar, K., Bercowtch, J., \& Oishi, M. (2002). The ASEAN way of conflict management: Old patterns and new trends. Asian Journal of Political Science, 10(2), 21-42.

Buzan, B. (2004). From international to world society? English school theory and the social structure of Globalization (Vol. 1). Cambridge: Cambridge University Press. 
Buzan, B. (2014). An introduction to the English school of international relations: The societal approach. Cambridge: Polity Press.

Chong Wu Ling, \& Sivachandralingam Sundara Raja. (2018). First Major Military Incursions in Sarawak, Sabah and Peninsular Malaysia during IndonesiaMalaysia Confrontation: Perspective of Selected Malaysian Englishlanguage Newspapers. JATI-Journal of Southeast Asian Studies, 23(2), 1-24.

Clark, M. (2013). The politics of heritage: Indonesia-Malaysia cultural contestation. Indonesia and the Malay World, 41(121), 396-417.

Dollah, R. M, \& Mohamad, AM. (2007). Malaysia-Indonesia barter trade: Opportunities and challenges. JATI-Journal of Southeast Asian Studies, 12(1), 411-419.

Druce, S. C., \& Baikoeni, E. Y. (2016). Circumventing Conflict: The IndonesiaMalaysia Ambalat Block Dispute. In M. Oishi (Ed.), Contemporary Conflicts in Southeast Asia (pp. 37-156). Singapore: Springer.

Elias, J. (2013). Foreign Policy and the Domestic Worker: The Malaysia-Indonesia Domestic Worker Dispute. International Feminist Journal of Politics, 15(3), 391-410.

Fitzpatrick, S. (2009). Malaysia steels Bali dance. The Australian. Retrieved from https://www.theaustralian.com.au/news/world/malaysia-steals-balidance/news-

story/cc2f15ea317b9b041caa59f07cd7b0f5?sv=6df7ecd8b1d324933ba22b240 $7453 \mathrm{e} 26$

Ford, M. (2006). After Nunukan: The regulation of Indonesian migration to Malaysia. In A. Kau \& I. Metcalfe (Eds.), Mobility, labor migration and border controls in Asia (pp. 228-247). Basingstoke: Palgrave Macmillan.

Hensel, P. R., Kim, H., \& Smith, D. (2008). Colonial Legacies and Territorial Claims: A Preliminary Investigation. Paper presented at the conference "National Territory and Sovereignty: Sixty Years since the Founding of the Nation," Seoul, South Korea, August.

Hindley, D. (1963). Foreign aid to Indonesia and its political implications. Pacific Affairs, 36(2), 107-119.

Karmazin, A. (2014). Introduction: English School Investigations at the Regional Level. In A. Karmazin, F. Costa-Buranelli, Y. Zhang \& F. Merke (Eds.), Regions in International Society: The English School at the Sub-Global Level (pp. 1-21). Brno-střed: Mazarik University Press.

Kaur, A. (2004). Crossing frontiers: Race, migration and border control in Southeast Asia. International Journal on Multicultural Societies, 6(2), 202-223.

Kim, H. J, \& Selvaraju, M. (2010). Reviewing ASEAN in 2010: From Vision To Action. JATI-Journal of Southeast Asian Studies, 15, 227-236. 
Linklater, A. (2005). The English School. In S. Burchill (Ed.), Theories of International Relations (pp. 84--110). Basingstoke: Palgrave-Macmillan.

Liow, J. (2003). Malaysia's illegal Indonesian migrant labour problem: In search of solutions. Contemporary Southeast Asia, 25(1), 44-64.

Long, S. (2014, 20 November). Asia: Safety in Numbers, The Economist. Retrieved from https://www.economist.com/news/2014/11/20/safety-in-numbers

Lumayag, L. A., \& Sail, R. M. (2014). Does Social Remittance Take Place Among Indonesian Plantation Workers in Malaysia? JATI-Journal of Southeast Asian Studies, 19, 102-116.

Mhd. Nur, M. S. (2018). Indonesia Malaysia Relations From the Perspective Of the Strait of Malacca. JATI-Journal of Southeast Asian Studies, 23(1), 64-74.

Nizar, M. (2017). Behind Cultural Legacy Conflict Between Indonesia and Malaysia. SOSIOLOGI: Jurnal Ilmiah Kajian Ilmu Sosial dan Budaya, 19(1).

Shafie, G. (1998). Reflections on ASEAN's 30 years and vision of the future. JATIJournal of Southeast Asian Studies, 4, 16-24.

Tangsubkul, P. (1982). ASEAN and the Law of the Sea. Singapore: Institute of Southeast Asian Studies.

Tempo.co. (2018, 26 May). Malaysia detains 6000 illegal Indonesian migrant workers. Tempo.co. Retrieved from https://en.tempo.co/read/news/2018/05/26/055918769/Malaysia-Detains6000-Illegal-Indonesian-Migrant-Workers

The Sun Daily. (2017, 9 July). Stop crackdown on illegal migrant workers: Indonesia. The Sun Daily. Retrieved from http://www.thesundaily.my/news/2017/07/09/stop-crackdown-illegalmigrant-workers-indonesia.

Wahyono, S. (2007). The Problems of Indonesian Migrant Workers' Rights Protection in Malaysia. Jurnal Kependudukan Indonesia, 2(1), 27-44.

Walt, S. M. (1998). International Relations: One World, Many Theories. Foreign Policy, 110, 29-46.

Wang, J., \& Buzan, B. (2014). The English and Chinese Schools of International Relations: Comparisons and Lessons. The Chinese Journal of International Politics, 7(1), 1-46. doi: 10.1093/cjip/pot017

Yazid, M. N. M. (2013). Malaysia-Indonesia Relations before and after 1965: Impact on Bilateral and Regional Stability (Note 1). Journal of Politics and Law, 6(4), 150-159. 